\title{
The Grammatical and Mechanical Errors of Students in Essay Writing
}

\author{
Siti Yuliah, Agustia Widiastuti, Ghea Resta Meida \\ Department of English, Politeknik Negeri Bandung \\ Bandung, Indonesia \\ E-mail: siti.yuliah@polban.ac.id, agustia@polban.ac.id, ghearesta16@gmail.com
}

\begin{abstract}
This study is about an analysis of grammatical and mechanical errors made by the students across the three levels of writing ability: high, average, and low. The grammatical and mechanical aspects analyzed were subject-verb agreement, sentence fragment, conjunction, capitalization, punctuation, and spelling. The present study aimed to find out the most common grammatical and mechanical errors and to identify the percentage of each error found in the essays. Students' essays taken from their English writing quiz were collected as the data since they might contain grammatical and mechanical errors. This study employed textual analysis and was supported by simple calculation to determine the frequency of each error found. The data were analyzed by identifying the errors, explaining why the errors are incorrect and writing the proper corrections, and evaluating the errors to get the percentage of each error found. The results showed that the most common grammatical error found is the use of conjunction, that is around $20.6 \%$, and the most common mechanical error found is punctuation by around $21.6 \%$.
\end{abstract}

Keywords: error analysis, grammatical errors, mechanical errors, essay writing, writing ability

\section{INTRODUCTION}

In learning English, grammar is associated with four skills: listening, speaking, reading, and writing (Morehouse, 2017). These skills have their own challenges. Writing, for example, is considered as the most difficult skill to learn since it requires not only good knowledge about grammar and vocabulary but also writing skills such as determining the structure, the content, and the organization of the essays (Richards \& Renandya, 2002, cited in Hourani, 2008). Writing is not only about good grammar but also about proper mechanics such as capitalization, punctuation, and spelling.

Errors made by the foreign language learners are mostly found in writing since writing is the most difficult skill in language. According to Nunan (1989), "writing is an extremely difficult cognitive activity which requires the learner to have control over various factors." One of the important aspects of writing is grammar. Writing with good structure and grammatical correct is very important for everyone. Understanding about 
the ideas that the students want to convey in their essays will be easier when they are conveyed with the correct grammar (Reinaldhi, 2017). Unfortunately, the most common error made by the students is the one related to grammatical structure. Besides grammar, mechanics such as capitalization, punctuation, and spelling are also the most common errors found in students' essays. It could happen as there are lots of grammatical and mechanical aspects should be understood. This study is conducted as an attempt to lessen the errors made by the students.

This study is aimed to find out the most common grammatical and mechanical errors found in 15 essays which were written by the second-year students of Department of English, Politeknik Negeri Bandung, and to identify the percentage of each error found in the essays. Furthermore, it is expected to help English teachers identify the most common grammatical and mechanical errors found in their students' essays, so they can help the students no to make the similar errors in their writing pieces. To formulate the objectives, this study attempts to seek the answers to the following research questions:

(1) What are grammatical and mechanical errors found in essays written by the students across the three levels of writing ability: high, average, and low?

(2) What is the most common error found in the students' essay writings?

\section{LITERATURE REVIEW}

Errors and mistakes are different. In language learning process, there are some errors and mistakes which are often made by students. Furthermore, James (1998) differentiates between errors and mistakes. According to him, errors are caused by the factors of understanding, ability or competence. When the language learners make an error, it is because they do not understand the linguistic system of the language being learned and can then be corrected by learning it again. Meanwhile, mistakes are not caused by the language learners' lack of understanding of the language used. They understand it, but they forget or mistaken when using it. To correct their mistakes, they can immediately correct them without having to learn it again. 


\section{Error Analysis}

Ellis and Barkhuizen (2005) state that error analysis is the process of determining the events, causes, and consequences of language failure. It can also be said that error analysis is done as an effort to find out the errors that learners made and can be an evaluation material for improvement. Moreover, Crystal (2003) defines error analysis as a technique to identify, classify, and explain the inappropriate forms which are made by foreign language learners (cited in Mungugu, 2010). Therefore, error analysis is a technique which is used to identify, classify, and explain errors made by second and foreign language learners in their language learning activity such as writing.

\section{Grammatical Error}

Grammatical error is a term used in order to tell inappropriate usage of grammar rules such as wrong verb tense (Nordquist, 2018a). Moreover, Novita (2014) believed that grammatical error is the error which occurs when words are not properly combined. Therefore, every grammar rule which is not applied correctly is identified as a grammatical error. Grammatical errors can be various since grammar consists of several parts such as adverbs, verbs, nouns, adjectives, prepositions, determiners, conjunction, and particles (Nordquist, 2018d). The present study focused on analyzing grammatical errors in subject-verb agreement, sentence fragment, and the use of conjunction.

\section{Subject-verb Agreement}

According to Benner (2000), a subject and a verb must agree with each other. A verb of a sentence must be singular if the subject is singular, and if the subject is plural, then the verb must also be plural. Corder (1974) explaines that there are five types of subject-verb agreement: subject-verb agreement of person, number, indefinite subjects, coordinated subjects, and notional agreement and proximity (cited in Radin and Fong, 2014).

1) Subject-verb agreement of person refers to whether the word signifies the first person, the second person, or the third person (Butte College, 2016c).

For example: $\underline{\text { Tanti }}^{(\mathrm{S})}$ goes $^{(\mathrm{V})}$ to school on foot every day.

2) "Subject-verb agreement of number refers to whether a word is singular (child, account, city) or plural (children, accounts, cities, we)" (Butte College, 2016c).

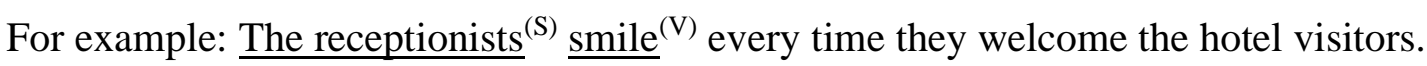


3) Subject-verb agreement of indefinite subject refers to "an unspecified or unidentified person or thing." (Nordquist, 2017b).

For example: Most students ${ }^{(\mathrm{S})} \underline{\text { understand }}^{(\mathrm{V})}$ about what their teacher explained.

4) Subject-verb agreement with coordinated subject refers to a subject consisting of two things and joined by and (Butte College, 2016c).

For example: Jan and $\mathrm{Kim}^{(\mathrm{S})} \underline{\text { have }}^{(\mathrm{V})}$ similar hobbies.

5) Subject-verb agreement of notional agreement means subject-verb agreement rules are applied which are based on the meaning of the sentence rather than the grammatical form (Brenner, 2012), and proximity means "the practice of relying on the noun that is closest to the verb to determine whether the verb is singular or plural" (Nordquist, 2017b).

Notional agreement example: Twenty-five dollars ${ }^{(\mathrm{S})} \underline{\text { is }}^{(\mathrm{V})}$ a reasonable price for this pair of shoes.

Proximity agreement example: Either mother or her children ${ }^{(\mathrm{S})} \underline{\text { have }}^{(\mathrm{V})}$ health food.

\section{Sentence Fragment}

Sentence fragment happens when sentences are not complete (Oshima \& Hogue, 1991) whether it lacks a subject, a verb, or a main clause.

Examples: 1. Always goes to work after cleaning his house. (Missing the subject)

Ramiro always goes to work after cleaning his house. (Correction)

2. People in my house. (Missing the verb)

People in my house have different hobbies. (Correction)

3. After she graduated from her college. (Missing the main clause)

She moved to Palembang after she graduated from her college.

(Correction)

\section{Conjunction}

"Conjunction is a word to connect clauses or sentences or to coordinate words in the same clause." (Oxford Dictionary, 2010). Stern (2003) states that there are three types of conjunction: coordinating conjunction, subordinating conjunction, and conjunctive adverb. 
1) Coordinating conjunction joins words with words, phrases with phrases, and clauses with clauses in a sentence (Walden University, 2017). It cannot connect sentences with sentences. Coordinating conjunction consists of the following coordinators: for, and, but, or, nor, yet, and so (FAN BOYS coordinators).

For example: The letter is $\frac{\text { short but } \frac{\text { interesting. }}{\text { word }} \text { word }}{\text {. }}$

2) Subordinating conjunction is a word that links two clauses to each other (Walden University, 2017). The clauses are not equal; one clause is the main clause (independent clause), and the other clause is the dependent clause preceded by subordinating conjunctions such as after, before, if, since, that, when, and which.

For example: My sister liked playing with dolls when she was a child. Independent clause Dependent clause

3) Conjunctive adverb is a conjunction which joins independent clauses into a sentence (Butte College, 2016a). A semicolon and a comma are needed if the conjunctive adverbs are placed in the middle of the sentences. The commonly used conjunctive adverbs are accordingly, besides, for example, however, in addition, meanwhile, moreover, on the other hand, otherwise, and therefore.

For example:

We must clean up our rivers and lakes; otherwise, the fish will die. Independent clause

Independent clause

\section{Mechanical Error}

Mechanical errors are different from grammatical errors. "Grammar is the structure of written or spoken language. It refers to the parts of speech and how they combine to form sentences. Mechanics refer to the rules of the written language, such as capitalization, punctuation, and spelling." (Lethbridge College, n.d.). Since mechanics are the part of writing, students also use mechanics in their essay writing in order to deliver clearer intended messages. Therefore, this present study also focused on mechanical aspects which comprise capitalization, punctuation, and spelling.

\section{Capitalization}

Capitalization means the first letter of a word is capitalized while the other letters of the word are in lowercase (Straus, 2018). There are eight main rules of capitalization according to Blanchard and Root (2004): capitalize the first letter of a sentence, names and the title preceding the name, names of racial and ethnic groups, names of specific 
places (countries, states, cities, rivers, streets, and mountains), days of the week, months, and holidays, names of religions, nationalities and languages, and all words in titles excluding prepositions, articles, and conjunction, unless they are the first word.

\section{Punctuation}

Punctuation is symbols or signs which are used in writings to tell the readers how the sentences are organized and how to read them ("Punctuation - Symbols and Signs", 2018). According to Blanchard and Root (2004), there are five main punctuation marks: full stop (.), comma (,), question mark (?), colon (:), and quotation marks ('...') and (“...”).

\section{Spelling}

Spelling is word forming which consists of acceptable ordered letters (American Heritage Dictionary, 2011). According to Cook (1999), there are four types of spelling errors explained as follows:

1) Substitution error occurs when a letter of a word is submitted by another letter, such as $\langle\mathrm{e}\rangle$ in dicided (decided), and $\langle\mathrm{i}\rangle$ in devided (divided).

2) Omission error occurs when a letter of the target word is omitted whether it is vowels or consonants, such as $\langle\mathrm{h}>$ in wich (which), and $<\mathrm{l}>$ specialy (specially).

3) Insertion error occurs when a letter is added to the target word, such as $\langle a\rangle$ in tray (try), <c > in reccommend (recommend), and <1> in gratefull (grateful).

4) Transposition error occurs when the order of two letters or more of the target word is reversed, such as <ie> in freid (fried), and sceince (science).

Previous studies have been done towards grammatical and mechanical errors in students' writing pieces. Abushihab (2014) has done An Analysis of Grammatical Errors in Writing Made by Turkish Learners of English as a Foreign Language. He discusses the contrastive analysis (CA) which is based on the structuralism and behaviorism formulated by Fries (1945) and developed by Lado (1957). The main purpose of CA is to compare phonological systems, syntax and lexical meanings of two or more languages. By comparing the foreign language and the native language of the students, teachers will know better the problems and can provide efficient and better methods for teaching the 
students (Ellis, 1985). He also admits that according to CA, errors are the results of differences between L1 and L2. He also noted that Mourtaga (2004) differentiate errors and mistakes, since errors can't be self-corrected and is caused by the learners' inadequate language of the target language while mistakes can be self-corrected. He also mentioned that Hourani (2008) points out that primary cause of errors are inter-lingual errors and intra-lingual errors. The formers are those which are related to the native language whereas the latter are those which are due to the language being learned.

For his study, Abushihab chose 20 second-year students at the Department of English Language learning English as a foreign language in Gazi University of Turkey. They were asked to write about the difficulties they face while learning English. The results showed that the participants made $15 \%$ errors on tenses, $28 \%$ on prepositions, $29 \%$ on articles, $9.6 \%$ on active passive voices, and $18.4 \%$ on morphology.

Khan and Khan (2016) emphasize how important Punctuation Marks in writing. They tried to compare the importance of punctuation used in writing with tone, pause, chunk used in speaking. They state that Punctuation Mark is one of the necessary elements that should be considered in writing besides other elements such grammar. As Rehman (2005) stated that all the writings require complete mastery of punctuation because it is punctuation which removes ambiguities and makes prose clear and easily comprehensible. Further he said that punctuation is a device used by a writer to help his readers understand the meaning of his words. His statement supports Iorio and Beyer's (2001) ideas that punctuation clarifies the meaning of the written sentence. Unfortunately, learners often ignore that important elements in their writing. Khan and Khan also admit that it is very beneficial for teachers to make their students master Punctuation Mark because it is very tough for a writer to deliver his ideas to his readers without using correct signs and symbols in the sentence. In this study, Khan and Khan chose only three punctuations. They are Comma, Colon, and Semi-colon. Sixty students of first and second year Punjab College Mianwali were chosen as participants. The results showed that errors analysis in the use of Comma mostly found on Error on Direct Quotation, Error to Set off the Address, Error to Set off Parenthetical Words and Phrases, Error to Set off Tag Questions, and Error to Separate Modifiers. The next analysis is the use Colon. Mostly students made the errors on: Error Before a Quotation, Error to Introduce the Effect, Error 
to Separate Chapter and Verse in a Scripture. The last error in punctuation made by the students are error analysis in the use of Semi-colon. Mostly students made the errors on Error Before Conjunctive Adverbs and Error When a Sentence has two Balanced but Separate Statements.

From the literature review above, this present study attempts to fill the gaps which are not found in the previous studies, namely grammatical errors on subject-verb agreement, sentence fragment, and the use of conjunction. Other gaps which are not also found in the previous studies, namely the errors found in the use of punctuation, capitalization, and spelling which are considered as mechanical errors are also presented here.

\section{METHODOLOGY}

This study employed textual analysis or grammatical analysis method since the data analyzed were in the form of text. However, the textual analysis method was only used in analyzing the grammatical and mechanical errors because the present analysis did not analyze the content or the intended messages which were contained in the essays. In addition, since one of the aims of this study is to identify the most common error found in the essays, the simple calculation for determining the frequency of each grammatical and mechanical error found was applied.

As suggested by Corder (1974) and summarized by Ellis and Barkhiuzen (2005), this study took four steps in analyzing the errors made by the students. The four steps are as follows:

\section{(1) Collecting Samples of Students' Essays}

Fifteen essays were selected purposively as the data to be analyzed. The essays were written by the second-year students of Department of English in the writing quiz. The teacher who taught writing class in Semester III was the one who categorized the students into the three levels of ability: high, average, and low at writing depending on their daily assignment scores, their midterm test score, and their final test score.

(2) Identifying the Errors

A linguistic unit which is considered as an unacceptable form from the system of the language learned is identified as an error. All of the errors found which are the focus 
of the present study were underlined and classified into six categories, whether they were errors in subject-verb agreement, sentence fragment, the use of conjunction, capitalization, punctuation, or spelling.

(3) Explaining the Errors

This step is an effort to explain why the errors found were wrong and to make the possible corrections of any errors found. The problems were solved in this step.

(4) Evaluating the Errors

The last step was error evaluation by calculating the errors found to get the percentage of each grammatical and mechanical error. In this step, the frequency of errors was identified, and the number of errors were presented in the forms of tables. By calculating the frequency of each error, it would be easy to determine the most common errors which students made in their essays. In addition, the result of this research was presented and arranged in the form of tables and charts for each category of grammatical and mechanical errors.

\section{The Participants and Research Site}

There were 55 essays written by the second-year students from two classes. The data consisted of seven essays written by high-ranking students, 43 essays written by middle-ranking students, and five essays written by low-ranking students. However, only 15 essays from the writing class were chosen. In selecting the essays from 55 to 15 , this research applied purposive sampling.

Therefore, the chosen essays were believed to be the representative of the whole population. The essays which were analyzed were taken from a writing quiz where the quiz was held in 60 minutes. The genre of the essay was Cause and Effect. The students were asked to choose one of the six suggested topics and were asked to develop the chosen topic into a five-paragraph essay.

\section{RESULTS AND DISCUSSION}

After the data were analyzed, the percentages of all errors found in 15 essays written by the students across the three levels of writing ability are compared. The distribution of the errors can be seen in Table 1. 
Table 1

Distribution of Types of Grammatical and Mechanical Errors

\begin{tabular}{|c|l|c|c|c|c|}
\hline \multirow{2}{*}{ No. } & \multirow{2}{*}{$\begin{array}{c}\text { Types of Grammatical } \\
\text { and Mechanical Errors }\end{array}$} & \multicolumn{3}{|c|}{$\begin{array}{c}\text { Numbers and Percentages of Errors } \\
\text { Made by Students Across Three Levels } \\
\text { of Writing Ability }\end{array}$} & \multirow{2}{*}{ Total } \\
\cline { 3 - 5 } & & $\begin{array}{c}\text { High } \\
\text { Ability at } \\
\text { Writing }\end{array}$ & $\begin{array}{c}\text { Average } \\
\text { Ability at } \\
\text { Writing }\end{array}$ & $\begin{array}{c}\text { Low } \\
\text { Ability at } \\
\text { Writing }\end{array}$ & \\
\hline 1. & $\begin{array}{l}\text { Subject-verb } \\
\text { Agreement }\end{array}$ & $11(28.9 \%)$ & $13(14.4 \%)$ & $17(22.4 \%)$ & $41(20.1 \%)$ \\
\hline 2. & Sentence Fragment & $3(7.9 \%)$ & $3(3.3 \%)$ & $10(13.2 \%)$ & $16(7.8 \%)$ \\
\hline 3. & The Use of Conjunction & $11(28.9 \%)$ & $19(21.1 \%)$ & $12(15.8 \%)$ & $42(20.6 \%)$ \\
\hline 4. & Capitalization & $1(2.7 \%)$ & $23(25.6 \%)$ & $6(7.9 \%)$ & $30(14.7 \%)$ \\
\hline 5. & Punctuation & $9(23.7 \%)$ & $22(24.5 \%)$ & $13(17 \%)$ & $44(21.6 \%)$ \\
\hline 6. & Spelling & $3(7.9 \%)$ & $10(11.1 \%)$ & $18(23.7 \%)$ & $31(15.2 \%)$ \\
\hline & Total & & & & $204(100 \%)$ \\
\hline
\end{tabular}

Table 1 shows the result of the errors found in 15 essays made by the students across the levels (high, average, and low). The errors committed by the students are classified under six categories. They are errors on subject-verb agreement, on sentence fragment, on the use of conjunction, on capitalization, on punctuation, and on spelling. The findings showed that the second year students of Department of English, Politeknik Negeri Bandung made 240 errors in total of which errors on punctuation by $21.6 \%$, followed by errors on the use of conjunction by $20.6 \%$, errors on subject-verb agreement by $20.1 \%$, errors on spelling by $15.2 \%$, errors on capitalization by $14.7 \%$, and errors on sentence fragment by $7.8 \%$.

For answering research question 1, the data on Table 1 explains grammatical and mechanical errors found in essays written by the students across the three levels of writing ability: high, average, and low.

a. The students with high level of writing ability made errors mostly on subject-verb agreement and on the use of conjunction by $28.9 \%$ for each error and on punctuation by $23.7 \%$. It means that there are three types of the highest errors. They are errors on subject-verb agreement, errors on the use of conjunction, and errors on punctuation. The following sentences are examples of errors showing error on subject-verb agreement, error on the use of conjunction, and error on punctuation. 
(1) In many cases, the children of divorced parents live as those children whose parents' marriages is still intact.

Error on Subject-verb agreement

Parents' marriages is a plural noun since there is an ending $-s$ after the word marriage. "The plural of a noun is usually made by adding $\mathrm{s}$ to the singular" (Thomson \& Martinet, 1985). Hence, the verb must be also in plural form to make it agree with the subject (Benner, 2000). It should be are rather than is since the linking verb is is used for singular noun. Therefore, the correct sentence is In many cases, the children of divorced parents live as those children whose parents' marriages are still intact.

(2) But how about seeing people fall out of love?

Error on the use of Conjunction

The sentence is preceded by the coordinating conjunction but. However, a sentence cannot be preceded by a coordinator since it links two independent clauses together in the same sentence ("Grammar: Conjunctions", 2017). The coordinator but can be replaced with a conjunctive adverb which has the same meaning as but. It can be replaced with nevertheless. Thus, the correct sentence is Nevertheless, how about seeing people fall out of love?

(3) Seeing people fall in love is one of the most magical things that a person can experience for love usually brings a lot of happiness.

Error on Punctuation

A comma (,) must be placed before coordinating conjunctions since it separates two independent clauses in sentences. Blanchard and Root (2004) said that one of comma functions is to separate two independent clauses. In the sentence, there is no comma which is placed before the coordinator for, so a comma must be placed after the first independent clause. Therefore, the correct sentence is Seeing people fall in love is one of the most magical things that a person can experience, for love usually brings a lot of happiness.

b. The students who are average at writing made mostly mechanical errors on capitalization by $25.6 \%$ and on punctuation by $24.5 \%$. The examples of errors made by the students with average level of writing ability on capitalization and on punctuation are as follows:

(1) In this era, Games is become more popular. Error on Capitalization

Games is not a proper noun, so it must not be capitalized. It should be written in lower case as long as it does not begin a sentence. Therefore, the correct sentence is In 
this era, games become more popular.

(2) When people have game addiction, they will play game without stop and they will play game to the point where they forget about time.

Error on Punctuation

A comma (,) must be put before any coordinating conjunctions which connect two independent clauses together. However, there is no comma placed before the coordinator and in the sentence. Therefore, the correct sentence is When people have game addiction, they will play game without stopping, and they will play game to the point where they forget about time.

c. The most common grammatical and mechanical errors found in essays written by the students who have low ability at writing are subject-verb agreement by $22.4 \%$ and spelling by $23.7 \%$.

The example of the two highest errors made by the students in this level are as follows:

(1) Those applications of media social usually using English.

Error on Subject-verb agreement

The sentence does not have its main verb because using cannot stand alone without an auxiliary. It can be changed into use since the subject is plural. Therefore, the correct sentence is Those applications of social medias usually use English.

(2) If parents ignore this eye desease, this is will be worst.

Spelling error

The right spelling for the underlined word is disease with $i$. Thus, the correct sentence is If parents ignore this eye disease, this will be worse.

For answering research question 2, the most common error found in the students' essay writings is punctuation with the percentage of $21.6 \%$ as shown on Table 1.

\section{CONCLUSION}

After analyzing 15 essays written by the students across the three levels of writing ability, there are 204 errors found. Errors on Punctuation got the highest frequency of error type $(21.6 \%)$, followed by errors on the use of conjunction $(20.6 \%)$, errors on subject-verb agreement $(20.1 \%)$, spelling errors $(15.2 \%)$, errors on capitalization 
(14.7\%), and sentence fragment errors (7.8\%). It can be concluded that the most common error found in the students' essay writings is errors punctuation with the percentage of $21.6 \%$.

Knowing the errors made by the students are beneficial for teachers to choose strategies or methods in teaching writing. For examples teachers should give much simpler exercise on writing and ask the students to apply the punctuation appropriately and correctly. The exercise should be given step by step from sentences to paragraphs, from paragraphs become a piece of an essay.

For further study, research on more specific punctuation could be conducted realizing that in this study the errors on punctuation are still general or too broad. As we know that Punctuation Marks have many kinds or symbols. In addition, a study for finding the reasons why the errors are made is necessary to be conducted.

\section{REFERENCES}

Abushihab, I. (2014). An analysis of grammatical errors in writing made by Turkish learners of English as a foreign language. International Journal of Linguistics ISSN 1948-5425 2014, Vol. 6, No. 4.

Benner, M. L. (2000). Self teaching unit: Subject-verb agreement. Online Writing Support. Retrieved from https://webapps.towson.edu/ows/moduleSVAGR.htm

Blanchard, K., \& Root, C. (2004). Ready to write more: From paragraph to essay. White Plains, NY: Pearson Education.

Brenner, E. (2012). Agreeing to disagree: Why we use "notional" agreement. Visual

Thesaurus. Retrieved from https://www.visualthesaurus.com/cm/wc/agreeing-todisagree-why-we-use-notional-agreement

Butte College. (2016a). Conjunctions. Retrieved from http://www.butte.edu/departments /cas/tipsheets/grammar/conjunctions.html

Butte College. (2016c). Subject-verb agreement. Retrieved from http://www.butte.edu /departments/cas/tipsheets/grammar/subject_verb.htm

Cook, V. (1999). Teaching L2 Spelling. Spelling Web. Retrieved from http://www .viviancook.uk/Writings/Papers/TeachingSpelling.htm 
Corder, S. P. (1974). Error analysis in Allen and Corder (eds) 1974.

Ellis, R. (1985). Understanding second language acquisition. Oxford: OUP.

Ellis, R. and Barkhuizen, G. (2005). Analyzing learner language. New York: Oxford University Press.

Fries, C.C. (1945). Teaching and learning English as a foreign language. Michigan: University of Michigan.

Hourani, T. M. Y. (2008). An analysis of the common grammatical errors in the English writing made by $3^{\text {rd }}$ secondary male students in the Eastern Coast of the UEA (Master's Thesis). Retrieved from https://bspace.buid.ac.ae /bitstream/1234/225/1/20050055.pdf

Iorio, M.G. and Beyer, C.E. (2001). The grammar cracker unblocks English grammar. USA: Vocalis Ltd., 100 Avalon Circle, Waterbury, CT 06710 USA.

James, C. (1998). Errors in language learning and use: Exploring error analysis. New York: Longman.

Khan, A.B. and Khan, M.Y. (2016). Punctuation Errors made by the Learners of Intermediate Level at Punjab Group of Colleges; an Error Analysis. International Journal of Institutional \& Industrial Research ISSN: 2456-1274, Vol. 1, Issue 1, Jan-April 2016, pp. 26-29.

Lethbridge College (n.d.). Grammar \& mechanics of writing. Retrieved from www.lethbridgecollege.net>writing

Morehouse, K. (2017). What are the four language skills? Lingua Core. Retrieved from https://www.linguacore.com/blog/the-four0skills/

Mourtaga, K. R. (2004). Investigating writing problems among Palestinian students: studying English as aforeign language. Bloomington, Indiana, Author House.

Mungugu, S. S. (2010). Error analysis: Investigating the writing of ESL Namibian learners (Master's thesis). Retrieved from uir.unisa.ac.za/handle/10500/4893.

Nordquist, R. (2017b). What is an indefinite pronoun? ThoughtCo. Retrieved from https:/ /www.thoughtco.com/what-is-an-indefinite-pronoun-1690951 
Nordquist, R. (2018a). Grammatical error definition and examples. ThoughtCo. Retrieved from https://www.thoughtco.com/grammatical-error-usage-1690911

Nordquist, R. (2018d). What is an English grammatical category? ThoughtCo. Retrieved from https://www.thoughtco.com/what-is-a-grammatical-category-1690910

Novita, R. (2014). An analysis of grammatical errors in the 1st year students' writings at English Department, Andalas University. Retrieved from Andalas UniversityF aculty of Humanities site: https://jurnalvivid.fib.unand.ac.id/

Nunan, D. (1989). Designing tasks for the communicative classroom. Cambridge University Press, United Kingdom.

Oshima, A., \& Hogue, A. (1991.). Writing academic English. California, CA: AddisonWesley.

Punctuation - Signs and Symbols. (2018). Skills You Need. Retrieved from https://www.skillsyouneed.com/write/punctuation1.html

Radin, N. N. M., \& Fong, L. L. (2015). Error analysis of subject verb agreement in argumentative essays among diploma students of UiTM Dungun, Terengganu. Research Gate, 677-688. Retrieved from https://www.researchgate.net/publication/271193000

Rehman, D. T. (2005). Punctuation, Comprehension, and Precis Writing. In D. Fazal-ulRehman, ENGLISH (COMPULSORY) (pp. 338-339). ISLAMABAD: Alama Iqbal Open University.

Reinaldhi, A. (2017). An analysis of tenses used on Motogp Official website articles. Unpublished Diploma 3 final project report, Bandung, Indonesia: Jurusan Bahasa Inggris, Politeknik Negeri Bandung.

Stern, G. (2003). Learners' grammar dictionary. Singapore: Learners Publishing Pte Ltd.

Straus, J. (2018). Capitalization rules. Grammar Book. Retrieved from https://www .grammarbook.com/punctuation/capital.asp

Thomson, A. J., \& Martinet. A. V. (1985). A practical English grammar. London, UK: Oxford University Press.

Walden University, Writing Center. (2017). Grammar: Conjunctions. Retrieved From https://academicguides.waldenu.edu/writingcenter/grammar/conjucntions 